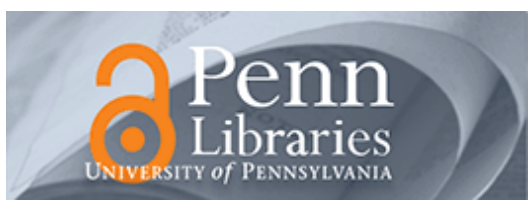

University of Pennsylvania
ScholarlyCommons

University of Pennsylvania Museum of Archaeology University of Pennsylvania Museum of Archaeology and Anthropology Papers and Anthropology

6-2001

\title{
Down the Garden Path: How Plant and Animal Husbandry Came Together in the Ancient Near East
}

Naomi F. Miller

University of Pennsylvania Museum, nmiller0@upenn.edu

Follow this and additional works at: http://repository.upenn.edu/penn_museum_papers

Part of the Archaeological Anthropology Commons

\section{Recommended Citation}

Miller, N. F. (2001). Down the Garden Path: How Plant and Animal Husbandry Came Together in the Ancient Near East. Near Eastern Archaeology, 64 (1/2), 4-7. http://dx.doi.org/10.2307/3210816 


\title{
Down the Garden Path: How Plant and Animal Husbandry Came Together in the Ancient Near East
}

\begin{abstract}
Frances M. Lappe's 1971 book, Dietfor a Small Planet, opened many eyes to the relationship between food supply and population. As the decades have progressed, it has become clear that solutions to overpopulation, environmental degradation, and loss of biodiversity must include an appreciation for diets that emphasize plant foods over animal products, because plants have the potential to feed more people from the same area. To get enough protein from a plant-based diet, however, a combination of foods must be consumed. Agricultural societies around the world independently solved this problem by developing cuisines based on cereals and pulses: maize and beans in the Americas, soybeans and rice in East Asia, wheat and barley and lentil, peas, and chickpeas in the Near East. Compared to the cuisines of our post-industrial processed food era, the diet of traditional peoples seems to be healthier-low in fat and sugar, high in vitamins, minerals, and complex carbohydrates, and with enough protein to maintain good health.

It is ironic that we now worry about population increase, tree-cutting, and ready access to meat, when long ago in the Near East these developments were the epitome of modernity. Around nine thousand years ago traditional mixed farming based mainly on plant and animal husbandry was in place: populations were expanding, fields were being cleared, and the nearest lambchop was no further away than your local sheepfold. Yet, one or two thousand years earlier, the only meat in the diet came from wild animals. Why did this change occur?
\end{abstract}

\section{Disciplines}

Archaeological Anthropology 



\section{Domestication}

The process of domestication began with morphologically wild plants and animals; the result was behaviorally and genetically different organisms. By the time archaeologists can demonstrate that the ancient seeds and bones themselves came from domesticates, people had been cultivating plants, and then herding animals, for some time. What is difficult to identify is the beginning of the domestication process, which by definition involves humans interfering with the life cycles of the plants and animals. In the Near East, the earliest domesticates were wheat, barley and pulses (e.g., lentil, bitter vetch, grasspea, pea, chickpea) then sheep, goat, pig and cattle.

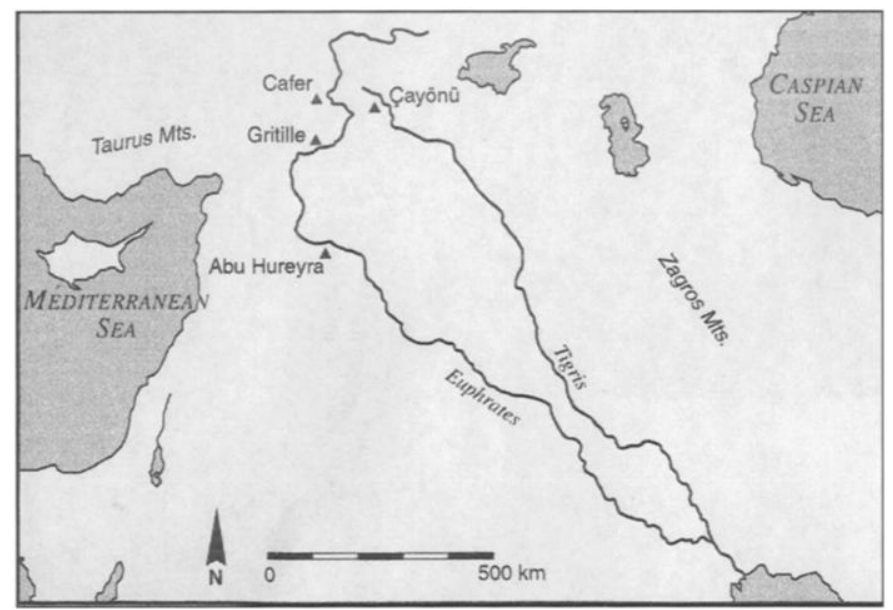

The locations of the Neolithic sites of Gritille, Cafer and Abu Hureyra near the Euphrates River.

Initially, people tended and adopted species that grew nearby. The period during which the full suite of plants, and later animals, were integrated into a single agricultural system over a wide area is called the aceramic Neolithic, and more specifically, the PPNB (Pre-Pottery Neolithic B; see Banning 1998 for a review). Several PPNB sites provide plant remains and other evidence that enable us to trace this process across time and space in a fairly restricted area: near the Euphrates River in southeastern Turkey, at Cafer and Gritille (Helmer 1988; de Moulins 1997; Voigt 1988; Stein 1989), and northern Syria, at Abu Hureyra (Moore et al. 2000; de Moulins 1997). Environmental variability in the form of increasing precipitation from south to north accounts for some of the differences between sites. But changes through time, as well as varying cultural practices account for others.

\section{The Evidence from Gritille in Regional Context}

The site of Gritille, a small village on the edge of the Euphrates River that was occupied between about 8500 and 7500 years ago provides a good case study for the course of domestication. The settlement lay within a rolling landscape that was once covered with oak-dominated steppe forest. The crop plants from Gritille are comprised of four cereals (two-row barley, einkorn, emmer and free-threshing wheat), four pulses (bitter vetch, lentil, grasspea, and pea) and flax. In the beginning, pulses made up an important part of the botanical remains. Without cooking, pulses are indigestible and two of them, bitter vetch and grasspea would retain their natural toxicity. Soaking in water-in the absence of pottery or metal vessels, this was probably accomplished in hide bags or in baskets set in the river-together with stone-boiling, would have eliminated these problems. This may explain the widespread use of cobble-filled pits throughout the PPNB.

Short of finding incompletely digested seed remains in a cess deposit, it is not so easy to prove that an archaeological seed is from food (Hillman 1997; Miller 1996; 1997). In some cases, a charred concentration suggests crop seeds had been accidently burned during processing or cooking. It is, however, likely that many seeds, both cultivated and wild, turn up charred in archaeobotanical samples because they had been incorporated in dung used as fuel, and so represent animal fodder (Miller 1984). Regardless of this interpretive problem, however, the relative amounts of the main cultigens in ordinary occupation debris suggest that over time, pulses decline in importance. In the early

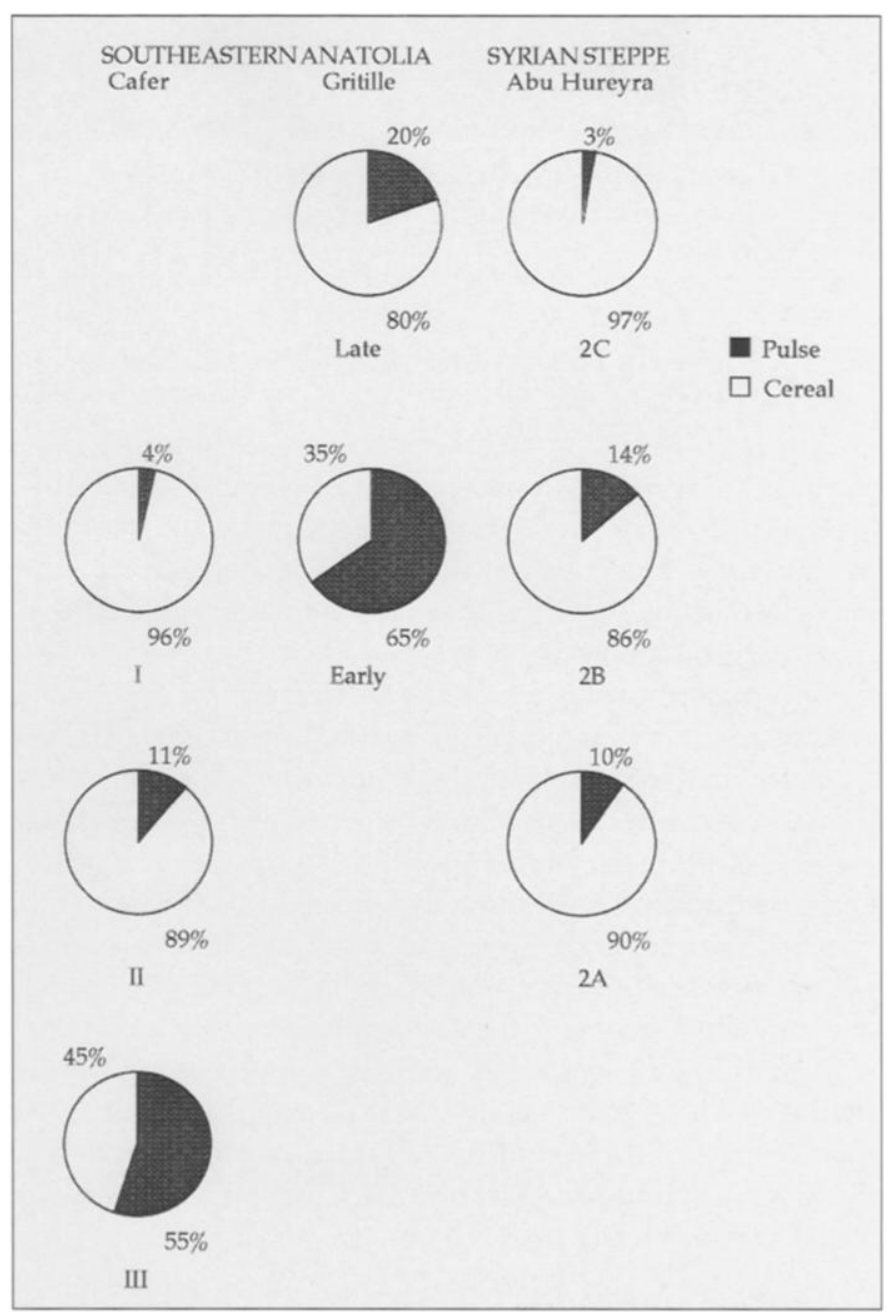

The relative amounts of cereals and pulses at PPNB sites near the Euphrates River. The circles represent those cultivated plants from the different strata at the three sites and are aligned chronologically. Thus Cafer I is roughly contemporary with Early Gritille and Abu Hureyra 2B. 


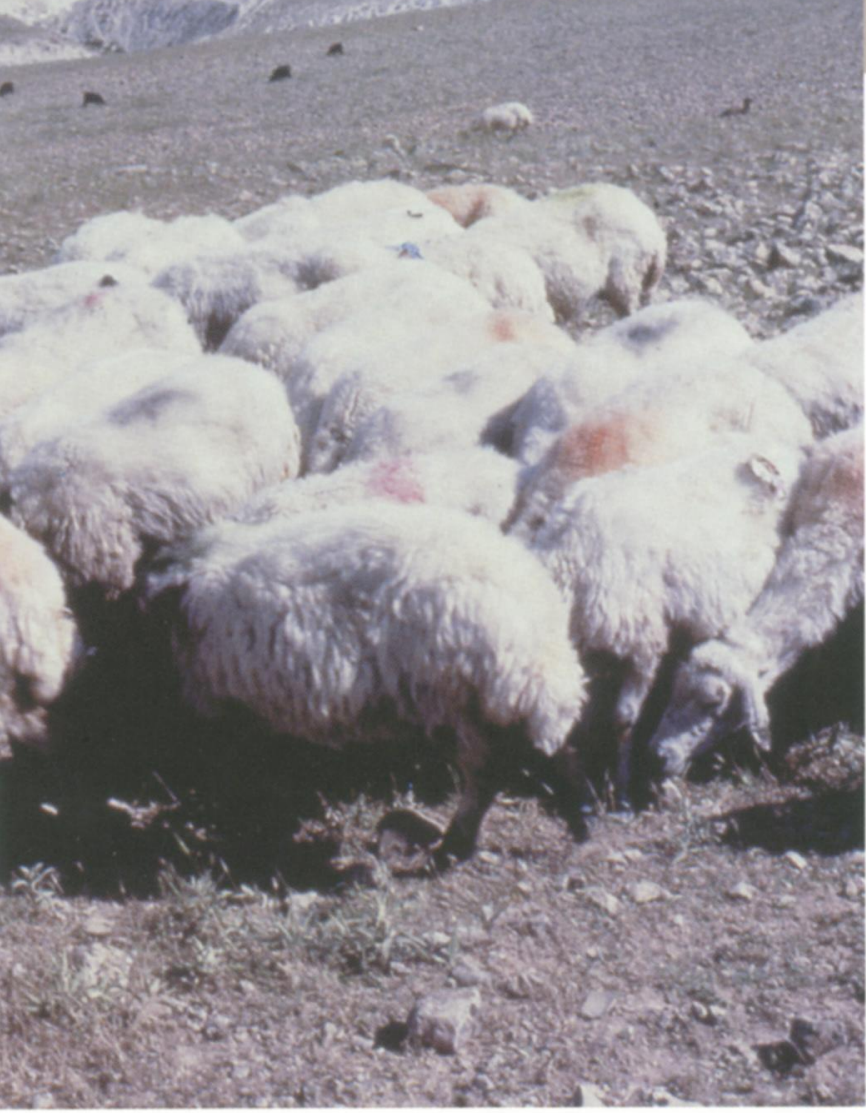

Flock of sheep produced by combining the stock of various owners in Biriman village, a small community near the Neolithic site of Gritille. Photo courtesy of Gil J. Stein.

phase at Gritille the pulse to cereal ratio is about 2:1, while in the late phase it is about 1:4.

During the PPNB, the most toxic pulses (i.e., bitter vetch and grasspea) decline in samples from trash deposits at Gritille. Lentils constitute about a third of the identified pulses in the trashy samples from the beginning, and about half of them at the end of the Gritille sequence. The proportion of cereals relative to pulses rises, and among the cereals, barley comes to predominate.

The importance of pulses can be put in a regional context. The assemblages from the more northern sites, Gritille and Cafer, show the same trend, namely, initially high proportions of pulses relative to cereals. Over the course of their respective PPNB occupations, pulses decline, though not uniformly. Thus pulses have nearly disappeared from the Cafer assemblage when Gritille has substantial amounts. The trend at the Syrian steppe site, Abu Hureyra, parallels that of southeastern Anatolia: although the amounts differ, pulses ultimately decline relative to cereals there as well.

Among the major cereals at Gritille, barley's importance relative to wheat increases significantly over time: in the early phase only $4 \%$ of the identified cereal is barley, whereas in the late phase its contribution rises to $62 \%$. Cafer and Abu Hureyra exhibit a similar trend.

\section{Environmental Constraints, Agricultural Development and Demand for Dung}

The changing patterns of crop choice that I have just described are obviously relevant to questions of agricultural development. Evidence from fuel remains, however, provides a more subtle indicator of the path of agricultural innovation during the PPNB. Most of the charred material found in occupation debris on Near Eastern archaeological sites was burned intentionally for fuel (Miller 1984). This generalization is most obvious for wood charcoal, but also may apply to seeds. In areas where dung was used as fuel, one might expect to find many seeds relative to charcoal. Conversely, if the primary fuel was wood, one would expect to see fewer seeds.

At Gritille, charred remains from the early and late occupations reflect well the changing pattern of land use in that the proportion of cultigens relative to charcoal increases, while numbers of seeds of wild plants relative to charcoal drops. Thus, dung fuel partially replaced wood fuel, perhaps due to the expansion of agricultural fields. The corresponding decline in wild seeds might reflect the practice of foddering animals with cultigens instead of sending them out to graze in uncultivated pasture.

As we might expect, woodland species are prominently represented in botanical assemblages from PPNB sites of the forest and steppe-forest zones, while the kinds of trees that grow along rivers predominate on steppe sites (Willcox 1992). That is, the charcoal remains, which reflect ancient fuel-gathering practices, come from the types

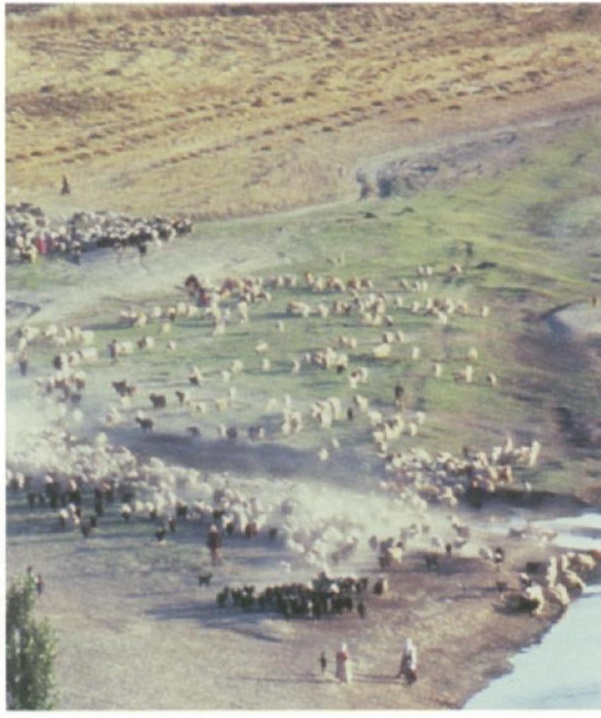

Flocks being watered near the Euphrates. Photo courtesy of Gil J. Stein. of wood that grew locally. When wood fuel is scarce or used up in an area, however, dung becomes an attractive alternative. Thus, in the moister, more wooded regions, seeds, especially of fodder plants, are relatively few. For example, Dominique de Moulins, who analyzed the botanical material from Cafer and Abu Hureyra (1997), reports far fewer seeds, either cultivated or wild, from the former than from the latter site. She also comments that, within the category of wild plants, the percentage of small legume seeds is highest in the earliest levels of Abu Hureyra. Going north from there, the proportions of small legumes decline.

How could people have used dung fuel before animals were fully domesticated? Although it is a matter of some debate, I think that even before plant cultivation, foragers living on the Syrian steppe supplemented their wood fuel supplies with gazelle dung (Miller 1996).As the process of animal domestication progressed during the PPNB (Stein 1989), we can be confident that people gained ever more access to animals and their dung. Thus, Cafer (ca. $9600-8200 \mathrm{BP}$ ) did not have morphologically domesticated animals, whereas Gritille (8500-7500 BP) does show evidence for increasing human control of sheep and goat. At Abu Hureyra, before $8500 \mathrm{BP}$, the animal bones come primarily from gazelle; 
after $8500 \mathrm{BP}$, the assemblage reflects the shift to sheep and goat exploitation, with a good chance that those animals had come under human control. Not until 8000 BP does the decline in small legumes suggest that the mixed farming economy was so successful at Abu Hureyra that overgrazing began to affect the natural vegetation adversely.

The gradual integration of animals into a mixed farming system can be traced in southeastern Anatolia. Where people used pulses most, they decline over the period when animal domestication was becoming established. This makes some sense on nutritional grounds, since, regardless of peoples' conscious knowledge, a steady supply of meat or milk satisfies the same human protein needs as the consumption of pulses together with cereals. Another pattern is the emphasis on wheat in the southeastern Anatolian sites. On environmental grounds, this is what we would expect. But why would both Gritille and Abu Hureyra show an increase in barley relative to wheat over time? Today in the steppe zone, animals must be given stored fodder during part of the year, and it is likely that in antiquity barley served that purpose.

The implications of these data are clear. Across space, charred food and fuel remains exhibit patterns that reflect changes in the aridity and natural vegetation cover from north to south along the Euphrates valley. Over time, patterns of crop use reflect the pace of integration of animal husbandry into the mixed-farming economy of the ancient Near East.

\section{Conclusions}

So the question remains, if a diet emphasizing plant foods is so beneficial, why would people have begun to tend animals? By raising domestic animals, the early farmers reaped the benefits of a mixed agricultural economy. First, as wild animals were hunted out by settled villagers who could no longer follow the game, domestic herds would have provided ready access to dietary fat; the Near Eastern oil-producing plants-olive, flax and sesame-were not to become important for many centuries. Second, even though land was available for agricultural expansion into new territory (and indeed a hallmark of the PPNB is its expansion), land around existing settlements would have been finite, so areas marginal for agriculture could have provided productive pasture. Third, herbivores would have converted inedible pasture plants into tasty meat, thereby increasing and evening out the annual food supply. As people integrated agricultural and pastoral production during the PPNB, they developed a subsistence system that, through its productivity and stability, allowed for larger permanent settlements and promoted population expansion into zones previously occupied solely by foragers.

Nowadays, we think of human population growth and attendant environmental degradation through deforestation and overgrazing as problems. We would solve them with sustainable practices such as energy conservation, the use of renewable energy sources, and a reduced consumption of animal protein and fat. But we should not be too hard on those Neolithic farmers who could not foresee the world they would bequeath to us.

\section{References}

Banning, E. B.

1998 The Neolithic Period: Triumphs of Architecture, Agriculture, and Art. Near Eastern Archaeology 61(4):188-237.

Helmer, D.

1988 Les animaux de Cafer et des sites précéramiques du Sud-Est de la Turquie: essai de synthèse. Anatolica 15: 37-48.

Hillman,G. C., Legge, A. J. and Rowly Conwy, P. A.

1997 On the Charred Seeds from Epipaleolithic Abu Hureyra: Food or Fuel? Current Anthropology 38: 651-55.

Lappé, F. M.

1971 Diet for a Small Planet. New York: Ballantine.

Miller, N. F.

1984 The Use of Dung as Fuel: An Ethnographic Model and an Archaeological Example. Paléorient 10(2): 71-79.

1996 Seed Eaters of the Ancient Near East: Human or Herbivore? Current Anthropology 37: 521-28.

1997 Reply (to G. Hillman). Current Anthropology 38: 655-59.

Moore, A. M. T., Hillman, G. C., and Legge, A. J.

2000 Village on the Euphrates. Oxford: Oxford University.

Moulins, D. de

1997 Agricultural Changes at Euphrates and Steppe Sites in the Mid-8th to the $6^{\text {th }}$ Millennium B.C. BAR International Series 683 . Oxford: British Archaeological Reports.

Stein, G.J.

1989 Strategies of Risk Reduction in Herding and Hunting Systems of Neolithic Southeast Anatolia. Pp. 87-97 in Early Animal Domestication and its Cultural Context, edited by P. J. Crabtree, D. Campana and K. Ryan. MASCA Research Papers in Science and Archaeology, Supplement to Vol. 6. Philadelphia: University of Pennsylvania Museum.

Voigt, M.M.

1988 Excavations at Neolithic Gritille. Anatolica 15:215-32.

Willcox, G.

1992 Timber and Trees: Ancient Exploitation in the Middle East: Evidence from Plant Remains. Bulletin on Sumerian Agriculture 6:1-32.

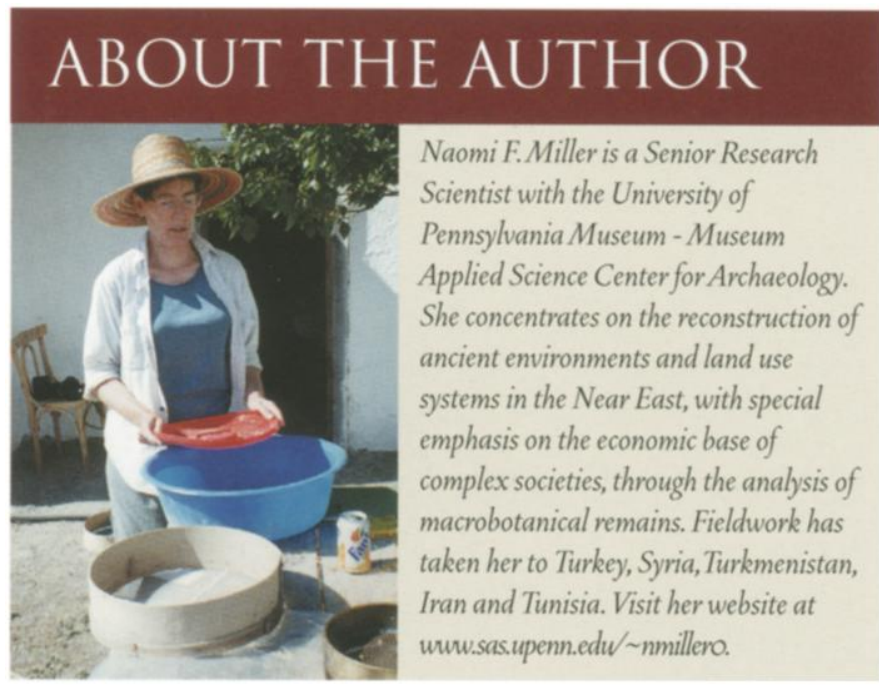

